\title{
Self Help, Media Cultures and the Production of Female Psychopathology ${ }^{1}$
}

\author{
Lisa Blackman ${ }^{2}$
}

\begin{abstract}
This article brings together work at the intersection of critical psychology and cultural studies to explore the psychological and cultural significance of women's magazine culture. Drawing on rhetorical psychology and Foucault's later work on 'techniques of the self' it explores the complex injunctions and positionings, which create the range of gendered anxieties and dilemmas produced within neo-liberal relations. Self help is discussed as a practice which condenses or brings together a range of cultural anxieties, bodily tensions, emotional economies and forms of psychopathology which are 'already-constituted' lived realities for many of the readers engaging with these magazines. The article concludes that more engagement with Critical psychology by cultural theorists will enable cultural studies to bring the body back into cultural theory, and to consider the translation of cultural injunctions across the designations of race, class, sexuality and gender.
\end{abstract}

Keywords: self-help, neo-liberalism and subjectivity, rhetorical psychology, dilemma, dialogue, magazine culture, post-feminism.

Resumo: Este artigo aborda conjuntamente trabalhos localizados na interseção entre a psicologia crítica e os estudos culturais para explorar a significação cultural e psicológica da cultura das revistas femininas. Apoiando-se na psicologia retórica e nos últimos trabalhos de Foucault sobre as 'técnicas do eu', ele explora as injunções e posicionamentos complexos, responsáveis pela criação de uma gama de ansiedades e dilemas ligados ao gênero, produzidos dentro das relações neoliberais. A auto-ajuda é discutida como uma prática que condensa, ou aproxima, uma gama de ansiedades culturais, tensões corporais, economias emocionais e formas de psicopatologias que são realidades vividas 'já-constituídas' para muitas das leitoras que convergem para estas revistas. O artigo conclui que uma maior aproximação dos teóricos culturais com a psicopatologia crítica permitirá aos estudos culturais trazerem o corpo de volta para a teoria cultural, e considerarem a tradução de injunções culturais através de designações de raça, classe, sexualidade e gênero.

Palavras-chave: auto-ajuda; neo-liberalismo e subjetividade; psicologia retórica; dilema; diálogo; cultura de revistas; pós-feminismo.

\footnotetext{
${ }^{1}$ Este artigo foi originalmente publicado no European Journal of Cultural Studies, vol. 7(2) 2004.

${ }^{2}$ Lisa Blackman é Senior Lecturer no departamento de mídia e comunicação do Goldsmiths College e trabalha na interseção dos estudos midiáticos com a psicologia crítica. Ela é particularmente interessada nas relações entre o corpo, o afeto e o psicológico. Seus livros mais recentes incluem Mass Hysteria: Critical Psychology and Media Studies, com Valerie Walkerdine (Palgrave, 2001), e Hearing Voices: Embodiment and Experience (Free Association Books, 2001). Ela tem dois livros a serem ainda publicados: The Body: The Key Concepts (Berg, 2008) and Immaterial Bodies: Affect, Relationality and the Problem of Personality (sob análise pela Duke University Press). Email: L.Blackman@gold.ac.uk
} 


\section{Introduction}

This article will provide ways of thinking through the cultural and psychological significance of media forms considered peculiarly feminine, and how these cultures work in conjunction with female psychologies. I will argue that although contemporary cultural studies is characterised by an 'anti-psychologism', many arguments engaging with the production of identity implicitly and often explicitly draw on generalist understandings of psychology in order to address the production of female subjectivities ${ }^{1}$. These understandings are hindered by essentialism, even when this reductionism has been most vehemently opposed. Generalist accounts are indicative of a more general reliance by social and cultural theory on sociological arguments, which examine the emergence of new forms of identity and subjectivity, created within changing social, cultural and governmental circumstances (Beck and Beck-Gernsheim 2001, Rose 1996). These arguments focus upon the production of particular kinds of psychology, through the ways in which institutional practices and the discourses that help to support them create particular kinds of self-practice and understanding. What is glossed over in these accounts, gestured to in some, but never given any serious analytic focus is the ways in which the injunction to understand one's life, for example as an autonomous individual, is culturally translated within the realm of popular discourse and can come to mean something entirely different when we look across the designations of race, class, gender and sexuality. This article will bring these arguments together by focusing specifically on magazine culture and what I will term the cultural production of female psychopathology.

One of the key questions raised by this work is how to understand an individual's subjective commitment or investment in particular fictional identities and practices of the self. Stuart Hall (1996) reminds us in his contestation of the 'problem of identity' that theories which can account for our investment in certain discourses, fictions and fantasies other than passive duping, or its counterpart, the voluntarism of

\footnotetext{
${ }^{1}$ For example, Beetham (1996) draws on Kristeva's account of feminine psychology to argue that the qualities of women's magazines, such as having many authorial voices and the mixing of medias and genres resists closure thus meeting or reflecting the psychology of its readers.
} 
many culturalist perspectives, is crucial to understanding media and cultural consumption beyond a model of encoding and de-coding. This model, Hall argues, relies upon a homogenisation of identity at the expense of any discursive understanding of the production of individual biographies and narratives. It would seem that the only knowledge we have as cultural theorists interested in these issues is Psychoanalysis, which Hall himself resurrects as a possible way of understanding this question.

Indeed psychoanalytic concepts are the mainstay of perspectives engaging with the embodiment of cultural categories mapping out the parameters of how these categories are seen to function. Franklin et al (2000), although not explicit about their reliance on psychoanalysis, invoke psychoanalytic concepts of fantasy and desire to explore the cultural purchase of self-health. Many cultural theorists developing studies of embodiment use the pioneering work of Homi BhaBha (1994) on the colonial stereotype to explore the relationship between visual representation and the mediation of social encounters through fantasies and fictions of Otherness organised through both a desire for and fear of the denigrated subject/object (Ahmed 2000). This work on raced subjects has provided an analytic vocabulary for exploring the mediation of one's relationship to one's own and another's body through the projection of certain fears and fantasies. This work is important for highlighting the interpenetration of the social and cultural with the subjective, but still for the most part engages with the body as text, rather than the ways in which actual subjects inhabit particular cultural categories. This is a more general problem with media and cultural studies which I explore with Valerie Walkerdine in Mass Hysteria (2001), a book which develops work in Critical Psychology at the intersection of media and cultural studies.

\section{Mass Hysteria}

In this book we argue that the anti-psychologism of cultural studies is largely a reaction towards Screen theory and the shift to the idea of specific gendered subjectivities within cultural locations rather than the grand totalising theories of femininity in the work of Laura Mulvey (1975) for example. This move is extremely important and cannot be overestimated in its critique of over general theories. Recent 
work within cultural studies revolves around the tension between those subject positions created within the text, and the question of subjective commitment or investment in those positions (Geraghty 1999, Stacey 1999, Hermes 1995). It is recognised that how actual women engage with the textual construction of femininity is 'complicated, contradictory and ambiguous' (Stempel Mumford 1998:121), and that there is no simple distinction to be made between the active and the passive audience. The problem however is still as Stacey (1999:263) cogently argues, how to argue for a 'feminine specificity without falling into the trap of biological essentialism'. I would argue that the issue of psychological essentialism is still important and often creeps in through the back door even when theorists are at pains to explore the subject as socially situated (Geraghty 1991, 1996).

It seems that Cultural studies is at a crossroads with the danger of either inscribing the homogenisation of identity to explain the social and cultural locations through which people consume media forms, or invoking a voluntarist subject who can ideally resist media influence ${ }^{2}$. This oscillation between what Hermes (1995:5) has termed concern and optimism has particularly structured feminists' encounter with media cultures which are considered specifically feminine. The paradox becomes one of how to talk about female genres, without assuming that the audiences are homogenous and characterised by their shared cultural codes or competences. Hall and Du Gay (1996:6) suggest, 'identities are (thus) points of temporary attachment to the subject positions which discursive formations construct for us'. The key question is how to explain and analyse audience investment and subjective commitment without imposing structural understandings of identity to read media consumption.

\section{Magazine Culture}

It is this problematic which this article will attempt to reformulate by working through some examples from a recent study of magazine culture ${ }^{3}$. The key focus of

\footnotetext{
${ }^{2}$ As Morley (1992:88) argues, the key concern is to explore, 'how members of different groups and classes, sharing different cultural codes, will interpret a given message differently, not just at the personal, idiosyncratic level, but in a way systematically linked to their socioeconomic position.'

${ }^{3}$ This study was funded by the AHRB, 'Inventing the Psychological: lifestyle magazines and the fiction of autonomous selfhood, AN6596/APN10894.
} 
this work is how to understand the governing of female bodies alongside arguments which suggest that women's magazines present an 'unfixing of femininity' (McRobbie 1999). The theoretical backdrop to these arguments comes from rhetorical psychology (Billig 1997) and the later work of Michel Foucault (1990) who was concerned with the kinds of relationships we develop with ourselves, what he termed, 'processes of subjectification'. Magazine culture is a good site for examining the kinds of cultural translations which occur in relation to recent sociological arguments which suggest that changing economic, social and cultural circumstances are creating new forms of subjectivity and social identity (Beck and Beck-Gernsheim 2001, Rose 1996). These arguments present over-general statements about new forms of selfhood, linked to novel governmental practices, such as neo-liberalism, which suggest that we are increasingly understanding success and failure as being subject to one's own efforts to constantly re-invent and transform oneself. . The lack of specificity and generality within these arguments leaves race, class, gender and sexuality as structural positionings enabling or constraining certain ways of understanding the world, rather than designations which are embodied and inhabited by actual subjects in complex ways.

The complexity of embodiment and its relationship to the dilemmatic ways in which discourses function and compete within particular contexts is crucial to understanding media consumption beyond a model of encoding and de-coding. The concept of dilemma is one which has framed many of the ways in which female magazine culture has been analysed. The concern with both the ways in which femininity is regulated as well as being shaped through a range of contradictory sites has set the parameters of debates within studies which oscillate between the 'fixing' and 'unfixing' of femininity (Ferguson 1983, Ballaster et al 1991, Beetham 1996). It is recognised that magazine consumption is highly complex and that readers' subjective commitment or investment is not 'directly connected with the narrative structure of these texts' (Hermes 1995:152).

Magazines at different historical moments have been credited with the power to dupe, particularly women's lives, provide forms of escapism to lives shot through with patriarchal fantasies, or as meaningless recipes of advice, confession and 
injunctions to consume which are picked up, put down but do not significantly shape how, (mainly women), think about their own aspirations, fears and desires. In line with the shift from structuralism to culturalism which is played out in the shift from text to audience within Anglo-American cultural studies, there is now more of a commitment to crediting audiences with the agency to resist media influence, often underpinned by an American discourse of empowerment (Walkerdine 1995). This shift is evident in the work of Angela McRobbie (1999), who within her own work on women's magazine culture has moved from a structuralist position, to one where alongside a change in media representations of femininity in such forms, women are now seen as both being enabled by and having increasing choice as to how they define themselves as women within neo-liberal societies. She argues that magazines increasing engagement with feminist issues and themes have transformed the genre to such an extent that the new fictional identities on offer un-make and re-make femininity beyond patriarchal concerns.

One issue then is the extent to which the contradictions and fractured themes through which 'new femininities' are articulated within the pages of these magazines represent an 'unfixing of femininity'? As a critical psychologist, concerned with the 'psychological' I want to suggest that there is no easy or straightforward inhabiting of any new cultural categories or identities, and that the unease, linguistic or otherwise, which is part of how categories function, create hesitancies rather than any simple identification on the part of readers or subjects (c.f. Riley 2000). McRobbie points to the ways in which most representations are raced, sexed and classed, excluding different sexualities as 'Other' whilst representations of black female subjectivities are relegated to a 'black genre', and class is almost entirely absent. The post-feminist woman may stand alone, single, happy, working on her self-confidence and achievements in her relationships and the workplace, while the stories of her sisters who cannot or who are unable to achieve such success stand as cautionary tales, marked out as pathological and seen to lack the psychological and emotional capacities to effect their own self-transformation. 


\section{Low Maintenance Self}

“Through therapy, I've learned how hard it is for me to express my displeasure to others. My family has always brushed things under the carpet and we talked about how this had made me nervous of confrontation. When Will felt bad and tried to manipulate me, I would react by trying to make things better. I responded to his mood rather than concentrating on how I was feeling. Anything to avoid a scene. I remember once being really chuffed when he told me I was a low maintenance girlfriend. Now I see that as an insult. After ten years of acting the same way, it's a relief when you realise it doesn't have to be like that any more. A year ago, the worst thing that could have happened to me was to lose Will. Now I'm glad it's finished and feel sad that I thought so little of myself I didn't leave before. I've been in therapy for six months now. Some weeks I'm ready to finish; others, I can't imagine life without it. I don't feel dependent on my therapist. I know this is something I'm doing for myself to make my life better.” (Marie Claire, September 2001 Relationship Rescue: Would Therapy Improve Your Love Life'.)

Arlie Hochschild (1994) has argued that the rise in advice books addressing the intimate lives of (mainly) women, are exemplary of the ways in which feminism has been transposed to address the concerns of the individualized (feminine) self. Her argument revolves around the assumption that what were once traditionally recognised as masculine 'feeling rules' now frame the kinds of injunctions which invite and incite women to be more emotionally detached and 'cooler' in relationships. Within this argument, feminism is one of the conditions of possibility for the translation of male feeling rules to create new feminine desires and expectations. However, this ‘right to emotionally detach' (ibid:15) is one which must be experienced as an act of honesty and authenticity, rather than submission to the wishes of an other (including in the above example, a therapist). Hochschild's use of the term 'abduction' in her discussion implies that this is a fraudulent translation of the aims of second wave feminism, arguing that the rise of advice books perform work in encouraging women to accept a concept of equality in her intimate relations, through her re-making as a self who can get by with relatively little support. Advice books are analysed as vignettes which contain 'magnified moments', which Hochschild suggests are indicative of the kinds of regulatory ideals being held up to women to understand their own conflicts and dilemmas. Comparing $19^{\text {th }}$ century advice books with those from the seventies to the nineties, she characterises their difference through contrasting images of the 'Traditional Woman' with the 'NoNeeds Modern'. 
The novel The Hours written by Michael Cunningham (1999) recently adapted to Hollywood by Paramount Pictures and Miramax Films (directed by Stephen Daldry 2003), depicts the lives of three women living in three distinct historical periods and two geographical locations, their stories intertwined and connected by Virginia Woolf's novel, Mrs Dalloway. Laura Brown living in suburban 1940’s America, played by Julianne Moore, epitomises Hochchild’s ‘Traditional Woman’ who ‘should accept patriarchy and keep the marriage (man) happy' (ibid:8). The 'dreaded moment' or feeling within this feminine regime is one where the woman feels anger and assertiveness or has strivings outside of the home and familial responsibilities. Laura Brown embodies the conflict surrounding the repudiation of her own needs through her struggles to find the time to 'lose herself' within her frantic reading of the life of Mrs Dalloway. The epiphany of this struggle is recalled in a moving scene in the film and book where Laura books a hotel room for the afternoon to read instead of baking the perfect birthday cake for her husband, Dan, and preparing for his return to the family home after work. The moment is dramatised in the film where the audience are constructed as witnesses to the 'dreaded moment' of Laura's striving for selfdetermination, signalled through her ferocious reading, alongside her contemplation of her own longing for death and the extent to which she feels able to choose to take her own life. This moment is restored through the burden of obligation she feels towards her son and husband and her desire to 'want' this normative set of expectations. This is followed by a scene where she drives to pick her son up from a neighbour, full of the scenes and images she has read, interspersed with the 'unreality' of her live as a wife and mother and her desire to end her worry, struggle and sense of failure.

In contrast what might the 'dreaded moment' be for what Hochschild (ibid) describes as the 'No-Needs Modern'? The No-Needs Modern Woman is one who is the first force in her own life and who is able to work on herself, through particular techniques of self-production, such that she can get by with relatively little support from others, and particularly men. The 'dreaded moment' is the desire to be taken care of, to be safe and warm, which is embodied in a fear of being dependent on another, even one's therapist. Hochschild relates this to a process of 'cultural cooling' in relationships more generally, which sociologists such as Lasch (1977) and Giddens 
(1991) have related to the cultural reconfiguration of ideas of love and commitment. Taking this 'dreaded moment' dialogically we can begin to think of the broader discursive context which has helped to produce this self/self and self/other relationship, and the dilemmas and conflicts which govern its production. Although on the surface women's magazines such as Marie Claire (UK) and Cosmopolitan (UK) appear to be sites where women's equality is celebrated and revered, the incitement to present oneself as a self-made or post-feminist woman involves the refutation and repudiation of a range of competing injunctions which construct feminine wants and desires in contradictory ways. These include the warrant or refuting of the kinds of discourses which Hollway (1984) characterises as traditionally aligning women with certain signifiers of relationship - the need for emotional closeness, security, commitment and so on and so forth. Hollway (1984) has argued that these kinds of concepts are part of a 'have-hold' discourse repudiated by feminism as patriarchal, which frames heterosex in a particular kind of way. This is an authoritative discourse which creates particular 'subject positions' through which people are able to understand and act upon themselves and position others. These concepts can also be differentiated through divisions which mark them out as signs of a person's emotional inferiority and weakness, i.e. as neediness, dependence, weakness and desperation, when they are read through some of the other discourses which govern what it means to be in relationship i.e. the permissiveness and sexual drive discourse (what Billig 1988 would term the 'argumentative context). Hollway argues that these discourses are profoundly gendered and have different consequences and implications depending on the person positioning and being positioned (c.f., Stenner 1993).

The self-made woman, rather than enacting choice and freedom, is obliged to disavow any desires for emotional security and safety, and to experience these as the outcome of her own desire for personal authenticity and self-development. It is within the interstices of these contradictory injunctions that self-help techniques, framed increasingly through the discourses of therapy and counselling, provide practices through which these self/self and self/other relations can be re-made. However, there are further dilemmas, tensions and conflicts which govern the production of this feminine subject. These tensions, contradictions and dilemmas are made visible when 
we look at the kinds of discourses which govern the dialogic relations which produce the feminine subject position of the 'low needs', 'low maintenance' self. Although singledom is celebrated as normative and not an indication of a woman's desperation, part of the warrant for the production of this feminine regime is an assumption and acceptance that many, if not a sizeable proportion of men are incompetent, and not worth waiting for. Women's choice in the matter is constituted as one of being 'too good' in diametric opposition to the construction of male incompetence, both in terms of emotionality and sexual technique and performance. This is mirrored in the pages of men's lifestyle magazines such as FHM and Loaded, where different kinds of techniques of self-production are pro-offered to men in order to become better lovers and partners. Although many of these techniques are framed by the discourses of the 'psy' disciplines (Rose 1990), their telos or goal are very different to those specifically addressing feminine anxieties and concerns. The dilemmas and anxieties which govern the production of the self-made or post-feminist woman add weight to Probyn's (1998:130) argument that there are at least two contradictory principles governing post-feminist regimes resolved through the invocation of the home as the 'natural' place to want to be; that 'the world's a crazy place and you have to fight for yourself but at the end of the day you can always go home'.

\title{
The Blob
}

\begin{abstract}
"Blame our education. Young women, you see, were schooled in the blob as a matter of necessity. While we were being savagely beaten on the rugby pitch, they were herded into special PE lessons, where a moustached lesbian rounders coach explained that the vending machine in the changing room did not, after all, dispense Revels. The closest we got to menstrual instruction, however, was a mumbling half-hour chat with the science teacher, where the alarming similarity between IUD coils and fishhooks stuck in the mind. Consequently, surfing the crimson wave became a mystifying feminine preserve just like going to the toilet in twos, or the enduring popularity of Ally McBeal. But the wise man realizes this is a hormonal cycle for two." (FHM September 2001. Periods: Read our essential guide to periods and battle her monthly blob no more.)
\end{abstract}

The dilemmatic argumentative context which shapes women's magazines exists alongside injunctions within men's magazines which fix women and their bodies within essentialist discourses which emphasize their unruly and unpredictable bodies. In the pages of men's magazines when men were presented with an injunction to work on relationships the kinds of practice they were encouraged to engage in were 
what I will term 'practices of self-mastery'. These practices encouraged men to acquire knowledge about women's bodies, usually as the article suggests, women's menstruating bodies, understood through scientific knowledge sanctioned within biological essentialist discourses. Where relationship is constructed as work, it is through techniques and practices which privilege particular kinds of knowledge acquisition which authorise and validate male authority and commentary. This is not about psychological re-invention or self-transformation, but intellectual mastery of the Other. These kinds of knowledge acquisition tended towards intellectual mastery of women's bodies which authorised and validated male authority and commentary. An important aspect of this construction of female subjectivity is the positioning of women through understandings of biology which emphasise the kinds of wild and animalistic outbursts likely to occur at the time of her periods.

Even though at one level success and satisfaction in relationship with an intimate other (woman) is presented as subject to the efforts, work and willingness of the men to engage in certain activities, the kinds of self-practice and selfunderstanding which govern what it means to 'work' at a relationship are radically different to those which address and govern women's concerns. This is in line with previous work on male magazines which underscore the way in which leisure is the trope through which relationships are generally understood and articulated, and that the kinds of injunctions pro-offered operate as defences against male vulnerability thus shoring up a particular version of masculine autonomy and independence (Stevenson et al 2000). When 'psy' techniques of self-production are more explicitly engaged with in men's magazines, the problematisation of male subjectivity is again radically different to the translation of women's concerns and anxieties in their own magazine culture. Techniques such as NLP (Neuro-Linguistic-Programming), for example, are presented as cynical practices which will enable a man to manipulate what is constructed as a woman's more complex sexuality, in order to improve his own sexual enjoyment and satisfaction. Male sexuality is constructed through what Hollway (1984) terms a 'male sexual drive discourse' where male desire is viewed as instinctual, base and simply biological. In contrast female sexuality is linked to emotionality and intimacy, more delicate and sensitive, located within the very signifiers of relationship which the self-made woman is required to disavow. The 
invocation of these radically contrasting differentiations, and the discourses which are repeatedly mapped onto them (these include the Madonna/whore dichotomy, women as passive/men as active, women as asexual and sexually unavailable/men as 'always already' ready for sex etc.), reproduce some of the most essentialised discourses of gender which many sociologists argue have been subject to processes of detraditionalisation (Featherstone 1990).

One further example will illustrate the complexity of the competing, contradictory injunctions which govern heterosexual female subjectivity within neoliberalism. I have already argued, drawing on the work of Hochschild (1994), that the shift from romantic discourses governing femininity, to those which advocate female self-determination, are produced through cultural practices which encourage women to construct themselves as selves who can get by with relatively little support. As Hochschild (ibid:14) argues, 'she ardently seeks to develop the capacity to endure emotional isolation. Parallel to the image of the low needs self, is the image of the self that ministers to itself. Who helps the self? The answer is the Self'. It is not the case that post-feminist women are not waiting for men, but that while they are waiting (for a man worth waiting for) they are encouraged to engage in emotional practices which produce them as feminine subjects who are capable of emotional detachment from others, but who are also capable of taking their own emotionality as an object of personal development and growth. What we might see as a re-traditionalisation or what Probyn (1998) terms a new-traditionalism is occurring in this process, whereby women are encouraged to work on themselves so that they remain open to relationships and do not become 'defensive'. The 'defensive self' is one where the very kinds of practices which enable the endurance of emotional isolation are those which are viewed as obstacles to the kinds of growth, maturity and self-development seen as underpinning the 'open' communication strategies essential to good relationships. This exists alongside the constitution of a 'dialogic unconscious' (Billig 1997) embodying disavowed desires for warmth, comfort, security and needing another. These concepts and the discourses they regulate appeared in the argumentative context as the unspeakable and yet affirmed categories. 


\section{Rhetorical Psychology}

Rhetorical Psychology (Billig 1988) is a strategic method which allows the dilemmas in speech and popular discourse to be examined in relation to a broader argumentative context. Relationship 'talk' and the different discourses which help to produce the conflicts and dilemmas facing individuals when reflecting on their desires for intimacy and their own autonomy is an interesting site for this kind of analysis.

Rhetorical psychology has been developed most convincingly in the work of Mick Billig, and is a useful approach to explore popular discourse as a set of situated practices, as it starts from the premise that popular discourse is dilemmatic. This work develops insights from the arguments of Bakhtin and Voloshinov concerned more with language use, the multi-accentuality of the sign and the 'dialogic unconscious' (Billig 1997). Popular discourse is structured through themes and contrary themes, which are contradictory and produce the kinds of 'thought space' which allow people to debate, disagree, argue and hold contradictory views. Popular discourse is not neatly systematised and the kinds of concepts and discourses which make people's self-understanding and practice intelligible are not necessarily easily available for analysis.

Where in the kinds of thematic analyses employed within magazine studies, a theme is a coherent, regulated cluster which can be read off from the surface of the magazine, the principles of rhetorical analysis pay attention to the often more implicit ways in which, dilemmas are being articulated, constructed and resolved. Rhetorical analysis makes a distinction between those themes, which, are explicitly expressed, and those which are implicit. Those which are implicit are conceptualised in such a way as to pay attention to the kinds of discourses and concepts they are implicitly refuting or refusing. Thus, the implicit, that is, what is absent or silent, if one remains at the surface level of the text, actually makes possible the particular form of articulation or argumentation. This is referred to as the contrary theme ${ }^{4}$ What is

\footnotetext{
${ }^{4}$ 'To bring these implicit meanings to the surface, the analyst faces a greater interpretative or hermeneutic task, for a counter-theme needs to be interpreted within discourse which seems prima facie to be arguing straightforwardly for a particular point. If contrary counter-themes can be said to be concealed within discourse, they are not hidden away in the way that Freudian theorists believe that certain inconsistent themes are hidden by repression from the conscious mind. The concealment is not a deliberate or even sub-conscious concealment, but may operate within layers of meaning of language. Discourse which seems to be arguing for
} 
unsaid is therefore as important as what is said and the analyst must attempt to engage with these contrary forces or 'counter-positions' (ibid:222) in relation to the wider argumentative context. This context helps to shape and create the dilemmas and contradictions which govern the kinds of thoughts and beliefs that people might be expected to hold.

As Billig (1997:225) argues in relation to the project of media and cultural studies, 'the meaning of any utterance, or piece of logos, must be understood in terms of its dialogical context, and this means in terms of the anti-logos, which it seeks to counter'. This kind of approach also begins to break down the idea of competing discourses to explore the kinds of tensions and cultural anxieties which help to produce as much as deny particular cultural categories and discourses. This conception of discourse is more dialogic and looks at how discourses speak to each other, through their disavowal, such that they are affirmed at the moments they are also denied ${ }^{5}$. This is important to begin to understand the kinds of linguistic tropes and positionings, performative acts and enactments of identity which can be analytically read from silence and absence as much as the more traditional focus upon those themes which repeatedly recur.

Alongside this conception of discourse as dialogic, attention was also paid to the kinds of self-practices which readers were encouraged to engage in, in order to resolve conflicts and to improve their success and satisfaction in the realm of intimate relationships. The later work of Michel Foucault (1990) on 'technologies of selfhood' was useful to explore what kinds of concepts and categories readers were encouraged to problematise themselves in relation to, and what kinds of practices of selftransformation they were encouraged to enact on the basis of these problematisations. The assumption within this work and its development within critical psychology and related disciplines, is that what we might term body techniques and practices, condense broader cultural values and discourses bringing to light the more normative

one point may contain implicit meanings which could be made explicit to argue for the counter-point. Thus discourse can contain its own negation, and these are part of its implicit, rather than explicit, meaning (Billig et al 1988:22)

${ }^{5}$ See an important development of this dialogic approach to discourse in the work of Jackie Stacey (1997) who analyses the unspeakable tropes of cancer and lesbian sexuality in her cultural study of cancer. She refers to them euphemistically as the C word and the L word. 
ways in which subjects fears, desires, aspirations and anxieties are shaped and defined (Blackman 2001, Franklin et al 2000). This focus can also begin to tell us about the cultural production of psychopathology and the way in which particular media and consumer cultures work in conjunction with and alongside 'already-constituted' fears and desires created in other social practices which 'make up' subjects lives. Nikolas Rose (1996) has used these kinds of methodological principles to analyse more regulated discourses, such as counselling and therapeutics. He has cogently argued that there is usually a privileging of the pathological over the normal in how subjects understand and act upon themselves. The important point is, therefore, how the arena of relationships is made intelligible and, what concepts allow the distinctions between the normal and the pathological to be thought? What is sanctioned or valorised as that which must be avoided, regulated, sought after or worked upon in order to manage the dilemma between being for example, a self-made woman and being in or wanting to be in a relationship with an intimate other?

These dilemmas, and indeed the potential psychopathology created for women by the ambivalence and contradiction produced through these tensions, are managed within the pages of women's magazines primarily by presenting women with the necessity of self-transformation and psychological re-invention as the means to improve satisfaction and success in intimate relationships. Women were primarily urged to work on relationships through an injunction which privileged their engagement in practices of self-monitoring, evaluation, scrutiny and bodily, emotional and/or psychological transformation in order to achieve certain desired ends. This project of self-transformation was also subsumed within a consumer discourse where diet programs, fitness, cosmetics, health oriented foods, cosmetic surgery and other body techniques were promoted and valorised through a vocabulary of choice which addressed the (female) reader as being able to achieve success and happiness through her choice amongst a range of options and preferences.

Thus the kinds of injunctions which social and cultural theorists have identified as characterising lived subjectivities under neo-liberalism, I would argue are culturally translated very differently when we look across the categories of gender. The kinds of argumentative spaces which govern what it means to be both an 
autonomous agent and desiring to be in a relationship with an intimate Other are governed through very different discourses and authoritative institutions and create very different dilemmas and resolutions to possible conflicts and struggles for men and women. The very difficulties of living the fiction of autonomous selfhood (Rose 1990) are contained within self-help discourses as potential stimuli for change and self-improvement. We must begin to recognise how an economy of pain, fear, anxiety and distress may be part of the apparatus through which this fictional identity is produced, lived and kept in place.

I am aware that the examples I have given are taken from what is a textual form of analysis and therefore it would be inappropriate to read off audience reception from such a study. However, what I am seeking to do is reformulate how we might consider the place of media texts in relation to broader cultures of femininity. This I would argue does highlight the need for media and cultural analysts to pay more attention to the dialogue and dilemmas which construct the argumentative spaces through which new feminine and masculine regimes are being constructed and transformed. How then can we think and re-think the cultural and psychological significance of these media cultures taking into account that 'media use is never an isolated process, but a collective process' (Hermes 1995:24)? How can we begin to engage with the question of subjective commitment and investment, which seem crucial in addressing the rise of self-help practices in our lives? Although I am not offering a foolproof method for re-conceptualising these concerns, I will point to some work within critical psychology on 'psychologies of survival' as signalling possible ways forward.

\section{Cultural Production of Psychopathology}

This focus would move beyond viewing identities as structural positions enabling or constraining certain ways of making sense of the world, and instead examine the kinds of psychopathology created at the interstices of the various contradictory discourses which govern people's lives. As we have already seen, what governs the kinds of discourses which frame the concerns of normative femininity within women's magazines are their inherently dilemmatic nature. Rather than simply competing with each other, discourses are dialogic, speaking to each other most 
visibly at their moments of disavowal or denial. The defensive organisation of the interconnections between those discourses which govern the production of modern femininities also I think reveals something about the embodiment of these discourses in actual women's lives. As argued earlier in this article, linguistic categories or discursive positionings are not inhabited with relative unease. Aside from the presumption of an agentic, voluntarist subject underpinning such formulations, this view also glosses over the psychopathology potentially produced by the dilemmas, ambiguities and contradictions which form normative femininity.

Valerie Walkerdine (1996) has explored the embodiment of such ambivalences and contradictions in the lives of a group of educated working class women who have entered typically middle class professions through education. Walkerdine argues that these women are positioned as the 'object of hopelessly contradictory discourses', being addressed as both autonomous, independent and in control through practices of consumption, leisure and advertising, as well as stupid, animal, reactionary, dependent and pathological through discourses, cultural and scientific, which construct the working class as Other (Blackman and Walkerdine 2001). Walkerdine develops BhaBha's (1994) concept of the 'colonial stereotype' to explore how class is both feared and desired, denigrated and envied. These ambivalences exist alongside the more normative addresses of consumer culture where selfhood is produced as a project of self-transformation and development. She explores how these contradictions are lived by these women through their own private sufferings and miseries which are not dealt with through stoic humour ${ }^{6}$, but through painful disclosure of the guilt, shame, humiliation and feelings of powerlessness and persecution they have experienced in wanting to 'get out', to leave the working classes behind. The discursive production of their forms of psychopathology are the very forms which are then read off within scientific discourses and practices as signs of working class inadequacy, inferiority or even biological illness (Blackman 1996).

\footnotetext{
${ }^{6}$ One of the more culturally sanctioned ways in which women have been able to 'speak' their pain is through humorous sound bites (c.f. H. Fielding, Bridget Jone's Diary, Picador Press, London and Basingstoke, 1997), or by being 'tough and witty' (c.f. Real Women, television drama broadcast in Britain in 1997).
} 
It is the very kind of psychopathology produced through these dilemmatic and contradictory discursive positionings, which women's magazines work alongside and in conjunction with. Particular problems of social existence such as losing one's job, health, beauty, relationships and friendships are constituted as stimuli for selfimprovement. The autonomous woman who does not lean on or need others and who above all can 'believe in herself' stands as the regulatory ideal in these addresses (Blackman 1999). The self-made woman waits for nobody and through her own hard work, effort and positivity makes things happen. The 'modern woman' gets, does, improves and rationalises her emotions on her path of self-transformation. Jackie Stacey (1997) talking about the kinds of personal narratives which tend to structure 'cancer stories' similarly argues that self-help or 'self-health' constructs suffering in a particular kind of way. Failure in these practices is constituted as a temporary obstacle to overcome, and as we have seen these practices map onto the very kinds of embodied experience which 'make up' many women's subjectivities ${ }^{7}$. Rather than simply viewing these resolutions and the practices promulgated on the basis of these self-relations as progressive and 'unfixing' femininity, I want to suggest that the dilemmatic quality of feminine discourses and the regulative practices pro-offered as resolutions, condense a range of bodily sensations, anxieties, tensions and forms of psychopathology which are 'already-constituted' lived realities for many of the readers engaging with these magazines. This work brings together much work in media studies analysing women's magazine culture, which both emphasises its fragmentary quality, but also the more systematic and repeated ways in which women are encouraged to see and understand themselves as subjects (Ferguson 1986). It allows us to explore the cultural purchase and potency of particular practices, as well as highlighting the need to reformulate studies of media consumption in relation to the embodied negotiation of the different kinds of cultural anxieties and personal tensions which readers bring to the text.

\footnotetext{
7 'In contemporary western culture, we are encouraged to think of ourselves as coherent stories of success, progress and movement. Loss and failure have their place but only as part of a broader picture of ascendance' (Stacey 1997:9).
} 


\section{Conclusion}

The arguments presented in this article suggest firstly that some of the general accounts of new forms of selfhood made by sociologists such as Beck and BeckGernsheim (2001) and Rose (1996) do not adequately engage with how these subject positions are translated within different media and cultural forms. The focus of this article has been specifically on gender and its centrality in re-configuring selfhood within media forms such as women's magazine culture. The injunction to understand one's life as an autonomous individual is governed through very different concepts, discourses and broader argumentative contexts, creating very different dilemmas and conflicts for men and women. The dialogic context of these discourses is also very different showing how the kinds of generalist accounts of subject formation do not engage with how they intersect across the designations of race, class, gender and sexuality. This work also suggests that studies of media consumption have for too long reified audiences as cognitivist subjects, primarily engaging with the media through linguistic structures and codes. This does not explore how certain cultural discourses and practices, such as self-help, condense or bring together a range of cultural anxieties, bodily tensions, emotional economies and forms of psychopathology which are 'already-constituted' lived realities for many of the readers engaging with these magazines. This is an approach to psychology which considers its cultural production through social and cultural practices, and also how media and cultural forms work alongside or in conjunction with these 'already constituted' fears and desires. The psychological dimensions of media and cultural forms are central to understanding how they work, particularly in terms of audience's investment or subjective commitment to certain practices and understandings. More engagement with Critical psychology by cultural theorists will enable cultural studies to bring the body back into cultural theory, to consider its regulation as well as the myriad of ways in which the dialogic nature of discourse creates the very dilemmas, conflicts and ambiguities which enable resistance and new forms of identity to emerge.

I would like to thank Joke Hermes and Ann Gray for their support for this article and for the very useful comments of the two anonymous reviewers. 


\section{Bibliography}

Ahmed, S. Strange Encounters: embodied others in post-coloniality. New York: Routledge, 2000.

Ballaster, R. Women's Worlds: ideology, femininity and the women's magazine. London: Macmillan, 1991.

Beck, U and Beck-Gernsheim, E. Individualization. London and New York: Sage, 2001.

Beetham, M. A Magazine of her own? Domesticity and Desire in the Women's Magazine. 1800-1914. London: Routledge, 1996.

BhaBha, H. The Location of Culture. London and New York: Routledge, 1994.

Billig, M et al. Ideological Dilemmas. A Social Psychology of Everyday Thinking. London: Sage, 1988.

Billig, M. 'Cultural Studies, discourse and psychology: From codes to utterances. In P. Golding and M. Ferguson (eds). Beyond Cultural Studies. London: Sage, 1997.

Blackman, L. 'The Dangerous Classes: Re-telling the Psychiatric Story. Feminism and Psychology. 6(3), 361-79, 1996.

Blackman, L. 'An Extraordinary Life: the Legacy of an Ambivalence'. New Formations 'Diana and Democracy' (special issue). 36, 111-24, 1999.

Blackman, L. Hearing Voices: Embodiment and Experience. London and New York: Free Association Books, 2001.

Blackman and Walkerdine, V. Mass Hysteria: Critical Psychology and Media Studies. Basingstoke and New York: Palgrave, 2001.

Featherstone, M. Consumer Culture and Postmodernity. London: Sage, 1990.

Ferguson, M. Forever Feminine. Women's Magazines and the Cult of Femininity. London: Heineman, 1983.

Foucault, M. The Care of the Self. The History of Sexuality Volume 3. London: Penguin, 1990.

Franklin, S, Lury, C and Stacey, J. Global Nature, Global Culture. London, Thousand Oaks, New Delhi: Sage, 2000.

Geraghty, C. Women and Soap Opera. Cambridge: Polity Press, 1991. 
Geraghty, C. 'Feminism and Media Consumption' in Curran, J, Morley, D and Walkerdine, V (eds) Cultural Studies and Communications. London: Edward Arnold, 1996.

Geraghty, C. 'Women and Soap Opera: A Woman's Space' in Morag Shiach (ed) Feminism and Cultural Studies. Oxford Readings in Feminism. Oxford and New York: Oxford University Press, 1999.

Giddens, A . Modernity and Self-Identity. Stanford: Stanford University Press, 1991.

Hall, S. 'Introduction' in Hall, S and Du Gay, P (eds) Questions of Cultural Identity. London: Sage, 1991.

Henriques, J et al. Changing the Subject. Psychology, Social Regulation and Subjectivity. London: Methuen, 1984.

Hermes, J. Reading Women’s Magazines. Oxford and Cambridge: Polity Press, 1995.

Hochschild, A. 'The Commercial Spirit of Intimate Life and the Abduction of Feminism: Signs from Women's Advice Books'. Theory, Culture and Society. Vol.11, pp1-24, 1994.

Hollway, W. 'Gender Difference and the Production of Subjectivity' in Henriques, J et al (1984) Changing the Subject. Psychology, Social Regulation and Subjectivity. London: Methuen, 1984.

Lasch, C. Haven in a Heartless World. New York: Basic Books, 1977.

McRobbie, A. In the Culture Society. London and New York: Routledge, 1999.

Morley, D. Television Audiences and Cultural Studies. London and New York: Routledge, 1992.

Mulvey, L. 'Visual Pleasure and Narrative Cinema'. Screen, (16) 3, 6-18, 1975.

Probyn, E (1997) 'New Traditionalism and Postfeminism: TV Does the Home' in C. Brunsdon, J, D’Acci and L. Segal. (eds) Feminist Television Criticism. A Reader. Oxford: Clarendon Press, 1997.

Riley, D. The Words of Selves: Identity, Solidarity, Irony. Stanford: Stanford University Press, 2000.

Rose, N. Governing the Soul: The Shaping of the Private Self. London and New York: Routledge, 1990.

Rose, N. Inventing Ourselves. Psychology, Power and Personhood. Cambridge, New York and Melbourne: Cambridge University Press, 1996. 
Stacey, J. Teratologies. A Cultural Study of Cancer. London and New York: Routledge, 1997.

Stacey, J. 'Desperately Seeking Difference' in M. Shiach (ed) Feminism and Cultural Studies. Oxford Readings in Feminism. Oxford and New York: Oxford University Press, 1999.

Stempel Mumford, L. 'Feminist Theory and Television Studies' in C. Geraghty and D. Lusted (eds). The Television Studies Book. London and New York: Arnold Press, 1998.

Stenner, P. 'Discoursing Jealousy' in E. Burman and I. Parker (eds). Discourse Analytic Research. London and New York: Routledge, 1993.

Stevenson, N, Jackson, P and Brooks, K. 'The politics of "new" men's lifestyle magazines', European Journal of Cultural Studies, Volume 3(3), 369-388, 2000.

Walkerdine, V. 'Subject to change without Notice.' in S. Pile and N. Thrift (eds) Mapping the Subject. London and New York: Routledge, 1995.

Walkerdine, V. 'Psychological and Social Aspects of Survival' in S. Wilkinson (eds). Feminist Social Psychologies. Buckingham and Philadelphia: Open University Press, 1996.

Walkerdine, V, Lucey, $\mathrm{H}$ and Melody, J. Growing Up Girl. Psychosocial Explorations of Gender and Class. Basingstoke and New York: Palgrave, 2001. 